\title{
Antibacterial Activity of Red yeast rice Extract against Propionibacterium acnes ATCC 11827 and Methicilin-Resistant Staphylococcus aureus ATCC BAA-1683
}

\author{
Tiana Milanda ${ }^{1}$, Ade Zuhrotun ${ }^{1}$, Ulya Nabila ${ }^{1}$, Vesara A. Gathera ${ }^{2}$, Arif S.W Kusuma ${ }^{1,3}$ \\ ${ }^{1}$ Department of Biological Pharmacy, Faculty of Pharmacy, Universitas Padjadjaran, \\ Bandung, West Java, Indonesia \\ ${ }^{2}$ Department for Pharmacology and Clinical Pharmacy, Universitas Padjadjaran, \\ Bandung, West Java, Indonesia \\ ${ }^{3}$ Department of Molecular Biosciences, Rutgers the State University of New Jersey, \\ United State of America
}

\begin{abstract}
Propionibacterium acnes (P. acnes) ATCC 11827 and Methicillin-Resistant Staphylococcus aureus ATCC BAA-1683 are bacteria that cause skin infections, namely acne vulgaris and skin and soft tissue infection/SSTI. The increase in the number of resistant bacterial strains, such as MRSA, requires the search for alternative antibiotics, including using natural ingredients. Red yeast rice is a product of rice fermentation by Monascus purpureus, which is known to have antibacterial, antifungal, antitumor, antioxidant, anti-inflammatory, anti-cholesterol and immunomodulator. This study aimed to determine the antibacterial activity of several red yeast rice extracts against these bacteria that cause skin infections. The research was carried out through the stages of collecting materials and identifying the yeast isolates, extracting of red yeast rice, phytochemical screening of red yeast rice extract, confirmation of bacterial test, preparation of bacterial test suspension, testing for bacterial resistance, testing for antibacterial activity of red yeast rice extract and determining the value of Minimum Inhibitory Concentration (MIC) and Minimum Bactericidal Concentration (MBC) of the most active extract. The results showed that the ethyl acetate and ethanol extracts had antibacterial activity against P. acnes ATCC 11827 and MRSA ATCC BAA-1683. Both extracts contain compounds from the polyphenols, flavonoids, quinones and saponins group. Ethyl acetate extract was the most active extract with MIC values against P. acnes ATCC 1182 and MRSA ATCC BAA- 1683 of $50 \mathrm{mg} / \mathrm{mL}$ and $12.5 \mathrm{mg} /$ $\mathrm{mL}$. The MBC values of ethyl acetate extract against these bacterial tests were $100 \mathrm{mg} /$ $\mathrm{mL}$ and $25 \mathrm{mg} / \mathrm{mL}$. The ethyl acetate extract is more active against MRSA ATCC BAA1683 than against $P$. acnes ATCC 11827. From the results of this study it is known that red yeast rice has activity against bacteria that cause skin infections, especially against MRSA
\end{abstract}

Keywords : Monascus purpureus, acne vulgaris, skin and soft tissue infection, Minimum Inhibition Concentration, Minimum Bactericidal Concentration

Corresponding author: Tiana Milanda. Department of Biological Pharmacy, Faculty of Pharmacy, Universitas Padjadjaran, Bandung, Indonesia. Email: tiana.milanda@unpad.ac.id

Received: 7 May 2021. Revised: 25 July 2021. Published: 13 August 2021 


\section{Introduction}

Acne or acne vulgaris is a skin disease that affects many Indonesians, especially teenagers. One of the bacteria that causes acne is Propionibacterium acnes (P. acnes), which is normal flora in the pilosebaceous glands, which under certain conditions can turn into opportunistic pathogens. ${ }^{1}$ In mild cases, acne can be treated using benzoyl peroxide or retinoids, while in moderate cases, a combination topical form of benzoyl peroxide or retinoids can be used with topical antibiotics. In severe cases, acne treatment needs to be added with oral antibiotics in the form of tetracycline, azithromycin and erythromycin. $^{2}$

Other skin infections that often occur in the community are skin and soft tissue infections (SSTI), such as impetigo, abscesses and cellulitis. SSTI is caused by the bacteria Staphylococcus aureus, MethicillinResistant Staphylococcus aureus (MRSA), Pseudomonas aeruginosa and Enterococcus species. MRSA is a strain of $S$. aureus that is resistant to beta-lactam antibiotics, including methicillin, as well as other antibiotics such as oxacillin, penicillin and amoxicillin. 2 If the cause of SSTI is MRSA, then the antibiotic of choice can be clindamycin, deoxycycline, ceftaroline or vancomycin. ${ }^{3}$

Currently, around $46 \%$ of antibiotics are used inappropriately and with incorrect indications. ${ }^{4}$ This condition triggers an increase in the number of bacterial strains resistant to antibiotics, so that it requires the search for alternative antibiotics, including those from natural ingredients. One of the natural ingredients that has potential as an antibiotic is red yeast rice. ${ }^{5}$

Red yeast rice is a product of rice fermentation by Monascus, especially Monascus purpureus (M. purpureus). In Asian countries, red yeast rice is used traditionally as a colorant, flavoring and natural food preservative as well as medicine. This fermented product of $M$. purpureus is known to contain various secondary metabolites, such as flavonoids, lovastatin (monakolin K), citrinin and various pigments from the polyketide group. These compounds are known to have activity as antibacterial, antifungal, antitumor, antioxidant, anti-inflammatory, anticholesterol and immunomodulatory. ${ }^{6}$

Various pigments of red yeast rice are known to have activity against Gram-positive bacteria such as Bacillus subtilis, Bacillus meganterium, Bacillus mycoides and Staphylococcus aureus, also against Gramnegative bacteria, such as Escherichia coli. This pigment also has antifungal activity against Aspergillus, Mucor, Penicillium citrinum and Fusarium. Until now, there is no information about the antibacterial activity of red yeast rice against $P$. acnes and MRSA. 5,7,8

In this study, the antibacterial activity of various extracts of red yeast rice were tested against $P$. acnes ATCC 11827 and MRSA ATCC BAA-1683. This study aimed to determine the potential of red yeast rice as a natural antibiotic to treat the infection of the two bacteria.

\section{Methods}

\section{Tools}

The tools used include analytical balance (Mettler Toledo AL204), maserator, rotary evaporator (Buchi Rotavapor R-300), autoclave (Hirayama, Japan), oven (Memmert 400-800), incubator (Sakura IF4), microscope (Olympus CK 40), 96 wellsmicroplate (Iwaki, Japan), 10-100 $\mu$ L volume micropipette (Biohit Proline), 100-1000 $\mu \mathrm{L}$ volume micropipette (Socorex Acura 825), blue and yellow micropipette tips, calipers, perforators and tools tools commonly used 
in the Natural Material Pharmacy Laboratory and the Pharmaceutical Microbiology Laboratory.

\section{Materials}

Materials used include red yeast rice (PT. Global Buana Mandiri, Jakarta), n-hexane (Bratachem), ethyl acetate (Bratachem), 96\% ethanol (Bratachem), sodium chloride (Merck), chloroform (Merck), ammonia (Merck), amyl alcohol (Merck), ether (Merck), hydrochloric acid (Merck), sulfuric acid (Merck), Mayer reagent (Bratachem), Dragendorff reagent (Bratachem), Liebermann Burchard reagent (Bratachem), magnesium powder (Bratachem), potassium hydroxide (Merck), Mc Farland standard solution 0.5, iron (III) chloride (Merck), gelatin (Bratachem), vanillin (Bratachem), dimethyl sulfoxide / DMSO (Merck), vaseline (Bratachem), oxacillin antibiotic disc (Oxoid), $\alpha$-naphthanol (Merck), crystal violet (Merck), lugol (Bratachem), safranin (Merck), cellophane plastics, filter paper (Whatman) and distilled water.

The test bacteria and comparison fungi used were $P$. acnes ATCC 11827 , MRSA

ATCC BAA-1683 and $M$. purpureus ITBCCL61 from the Laboratory of Microbiology and Bioprocess Technology, Chemical Engineering Study Program, Faculty of Industrial Technology, Institut Teknologi Bandung. The bacteria and fungi medium used were Mueller Hinton Agar/ MHA (Oxoid), Mueller Hinton Broth/ MHB (Oxoid), Saburoud Dextrose Agar/ SDA (Oxoid), Triple Sugar Iron Agar/ TSIA (Oxoid), Sulfide Indole Motility/SIM (Difco), Methyl Red-Voges Proskauer/MRVP (Difco), Simmon's Citrate Agar/SCA (Oxoid), glucose (Oxoid), sucrose (Oxoid), lactose (Oxoid), mannose (Oxoid), maltose (Oxoid) and peptone (Oxoid).
Material Collection and Identification of Mold Isolates

Molds were isolated from red yeast rice and identified macroscopically and microscopically by comparison with $M$. purpureus ITBCCL61. ${ }^{9}$ As much as $1 \mathrm{~g}$ red yeast rice finely crushed, then suspended 5 $\mathrm{mL}$ of sterile distilled water. Red yeast rice suspension and $M$. purpureus ITBCCL61 culture each was inoculated onto the SDA surface in a petri dish, then incubated at room temperature for 5-7 days. Macroscopic observations were made on the shape and color of the colonies of the two molds. Microscopic observations were made of the molds grown using the moist chamber method. The forms of hyphae, conidia and ascospores of both fungi were observed and compared under a microscope.

\section{Extraction of Red Yeast Rice}

Red yeast rice was extracted by multilevel maceration method using three solvents with different polarity, namely n-hexane (non polar), ethyl acetate (semi polar) and ethanol $96 \%$ (polar). ${ }^{10}$ A total of $2 \mathrm{~kg}$ of red yeast rice was macerated with $2 \mathrm{~L}$ of n-hexane for 24 hours at room temperature. The liquid extract was filtered, then the maceration process was repeated several times until a clear filtrate was obtained. The extract residue was dried, then macerated in the same way using ethyl acetate and $96 \%$ ethanol. Each extract was thickened using a rotary evaporator at a speed of $60 \mathrm{rpm}$ at $50{ }^{\circ} \mathrm{C}$ until the weight was constant. The three extracts were observed organoleptically, then the yield was determined.

Phytochemical Screening of Red Yeast Rice Extract

Phytochemical screening of red yeast rice extract was carried out using the Fransworth method (1966). ${ }^{11}$ Screening was carried out on alkaloid, tannin, polyphenol, flavonoid, steroid, triterpenes, monoterpenes, 
sesquiterpenes, quinone and saponin class compounds.

\section{Confirmation of Test Bacteria}

The test bacteria in the form of $P$. acnes ATCC 11827 and MRSA ATCC BAA16 were confirmed through microscopic observation using Gram stain and through biochemical tests. ${ }^{12}$ The biochemical tests that were carried out included the carbohydrate fermentation test, the MR-VP test, the citrate test, the motility test and the urea test.

\section{Preparation of Test Bacteria Suspension}

P. acnes ATCC 11827 and MRSA ATCC BAA-1683 were inoculated onto the MHA surface, then incubated at $37{ }^{\circ} \mathrm{C}$ for $18-24$ hours. Both bacterial cultures were suspended in a $0.9 \%(\mathrm{w} / \mathrm{v})$ sodium chloride solution. The turbidity of the suspension was adjusted to the turbidity of the McFarland standard solution of 0.5 which was equivalent to $1.5 \mathrm{x}$ $108 \mathrm{CFU} / \mathrm{mL}$.

\section{Bacteria Resistance Testing}

The MRSA ATCC BAA-16 resistance test to oxacillin was carried out using the agar diffusion method with the paper disc technique. ${ }^{14}$ The bacterial suspension was inoculated on the surface of the MHA in a petri dish, then a $1 \mu \mathrm{g}$ oxacillin antibiotic disc was placed on the agar surface. The plates were incubated at $37^{\circ} \mathrm{C}$ for $18-24$ hours, then the diameter of the inhibition was measured using a caliper.

\section{Testing Antibacterial Activity of Red Yeast Rice Extract}

Red yeast rice extract was tested for its antibacterial activity against $P$. acnes ATCC 11827 and MRSA ATCC BAA-1683 using the agar diffusion method with the perforation technique. ${ }^{13}$ The three extracts were diluted using 2\% DMSO (v/v), resulting in several variations in extract concentration. A total of $20 \mu \mathrm{L}$ of each tested bacterial suspension was put into a sterile petri dish, then $20 \mathrm{~mL}$ of liquid MHA was added. The mixture was shaken slowly until homogeneous, then allowed to solidify.

The medium was perforated using a perforator with a diameter of $8 \mathrm{~mm}$, then filled with 50 $\mu \mathrm{L}$ of various extract concentrations. As a comparison, a petri dish containing MHA (negative control), MHA inoculated with the test bacteria (positive control) was prepared, and MHA inoculated with 2\% DMSO (v/v) (solvent control). All petri dishes were incubated at $37{ }^{\circ} \mathrm{C}$ for $18-24$ hours. The antibacterial activity of the extract in the form of the inhibition area around the hole was measured using a caliper. Measurement results were compared between extracts to determine the most active extract.

Determination of Minimum Growth Inhibitory Concentration (MIC) and Minimum Killing Concentration (KBM) of Red Yeast Rice Extract

The most active red yeast rice extract is determined by the Minimum Growth Inhibitory Concentration (MIC) and the Minimum Killing Concentration (KBM) using the microdilution method. ${ }^{15}$ The extract was dissolved in 2\% DSMO (v/v) as a stock extract solution. The concentration of the tested bacteria was adjusted, so that each well contained 3.75 x $105 \mathrm{CFU} / \mathrm{mL}$.

Column 1 to column 12 of microplates each inserted $100 \mu \mathrm{L} \mathrm{MHB}$. Column 3 and 4 were added by $100 \mu \mathrm{L}$ of Red yeast rice extract, then homogenized. The stratified dilution was carried out by pipetteing $100 \mu \mathrm{L}$ from column 4 to column 5 , then the mixture was homogenized. The next dilution was carried out in the same manner until the column 12 , then the $100 \mu \mathrm{L}$ from the last dilution was discarded. To the column 2, 4 until column 

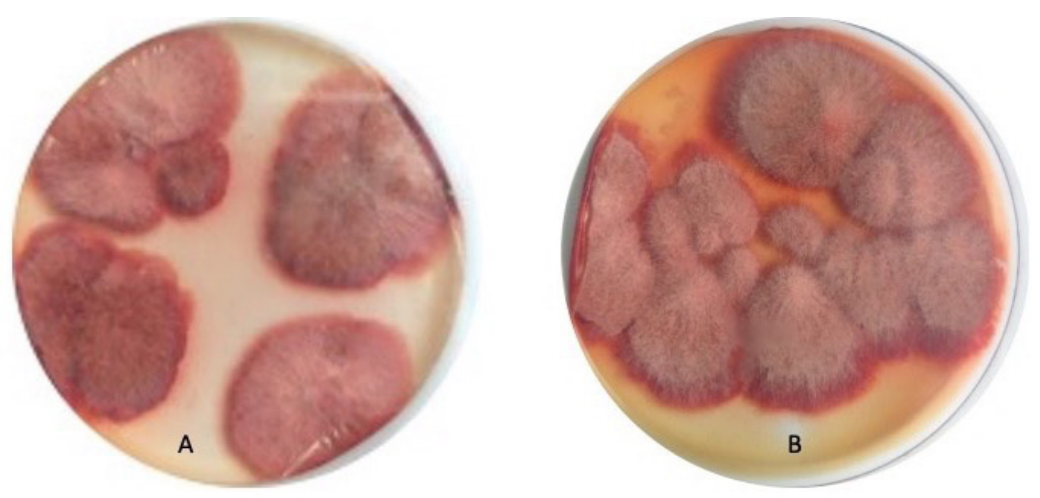

Figure 1. Macroscopic observation results of (A) mold isolated from red yeast rice (B) Culture of M. purpureus ITBCCL61
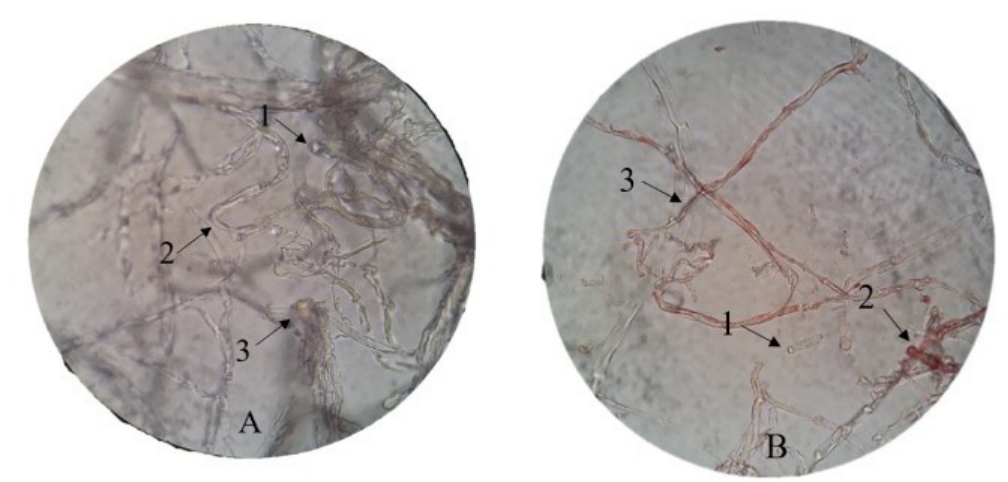

Figure 2.Microscopic observation results of (A) molds isolated from red yeast rice (B) culture of Monascus purpureus ITBCCL61 (1) conidia, (2) ascospores, (3) hyphae

$12,10 \mu \mathrm{L}$ of the tested bacterial suspension were added. Column 1 functions as negative control, column 2 functions as positive control, while column 3 functions as extract control. The microplates were covered using cellophane plastic, then incubated at $37{ }^{\circ} \mathrm{C}$ for 18-24 hours. MIC value was determined from the column with the smallest extract concentration that appeared clear (no bacterial growth).

Determination of the KBM value of the extract is carried out by scraping the solution from the last few columns that appeared clear on $5 \mathrm{~mL}$ MHA in a petri dish. Petri dishes were incubated at $37^{\circ} \mathrm{C}$ for $18-24$ hours. The $\mathrm{MBC}$ value was determined from the extract concentration which did not show the growth of bacterial colonies.

\section{Results and Discussion}

Material Collection and Identification of Mold Isolates

Macroscopic observations of mold isolates and M. purpureus ITBCCL61 showed colonies with white hyphae, which a change in color to orange and then to red, with increasing incubation time (Figure 1). The same colony shape and color is also shown by M. purpureus isolated by Manan, et al. (2017). The growth medium also turned red, due to the presence of $M$. purpureus pigments which was diffused into the medium. ${ }^{9}$

The microscopic observations of the two mold cultures show the same characteristics of hyphae, conidia, and ascospores (Figure $2)$. Both have somatic hyphae, which were composed of branched mycelium, clear to 
Table 1. Results of Phytochemical Screening of Red Yeast Rice Extract

\begin{tabular}{lccc}
\hline $\begin{array}{l}\text { Compound } \\
\text { Group }\end{array}$ & $\begin{array}{c}\text { n-hexane } \\
\text { Extract }\end{array}$ & $\begin{array}{c}\text { Ethyl Acetate } \\
\text { Extract }\end{array}$ & $\begin{array}{c}\text { Ethanol } \\
\text { Extract }\end{array}$ \\
\hline Alkaloids & - & - & - \\
Tannins & - & - & - \\
Polyphenols & - & + & + \\
Flavonoids & + & + & + \\
Steroids and Triterpenes & - & - & - \\
Monoterpens and Sesquiterpenes & - & - & - \\
Quinone & + & + & + \\
Saponins & - & + & + \\
\hline
\end{tabular}

Information: $(+)=$ positive

$$
(-)=\text { negative }
$$

brown and insulated (septate). Conidia are globular and clear in color, while ascopora are round or slightly oval in shape. The same observation results are also shown by $M$. purpureus that was isolated by Manan, et al., 2017. ${ }^{9}$ Based on these observations, it is found that the mold isolate was M. purpureus.

\section{Red Yeast Rice Extraction}

The results of organoleptic observations of red yeast rice extract showed that the three extracts were in the form of a thick liquid, distinctive smell, with n-hexane extract with a slightly orange color, ethyl acetate extract with a red color, and ethanol extract in red. Of the $2 \mathrm{~kg}$ of red yeast rice, $53.36 \mathrm{~g}$ of $\mathrm{n}$-hexane extract $(2.67 \% \mathrm{w} / \mathrm{w}), 84.22 \mathrm{~g}$ of ethyl acetate extract $(4.21 \% \mathrm{w} / \mathrm{w})$, and $192.09 \mathrm{~g}(9.60 \% \mathrm{w} / \mathrm{w})$ of ethanol extract were obtained. The extract with the highest yield was ethanol extract, followed by ethyl acetate and n-hexane extracts. The same results were obtained by Ismail, et al. (2016) which produced a yield of $9.44 \% \mathrm{w} / \mathrm{w}$ of the ethanol extract of red yeast rice. ${ }^{16}$

Phytochemical Screening of Red Yeast Rice Extract

The results of phytochemical screening of red yeast rice extract show that the n-hexane extract contained compounds from the flavonoid and quinone groups, while the ethyl acetate and ethanol extracts contained compounds from the polyphenol, flavonoid, quinone and saponin groups (Table 1). A research by Kongbuntad \& Asenphet (2016) showed that the water extract of red yeast rice contained terpenoids, triterpenoids, flavonoids, phenols, plobatin, coumarin and saponin research, while the research of Ismail, et al (2016) showed that the ethanol extract of red yeast rice contained flavonoids, alkaloids and saponins. The difference in results is due to differences in the red yeast rice that are used as research objects. ${ }^{16,17}$

Based on the results of phytochemical screening, it is suspected that the antibacterial activity of red yeast rice extract comes from polyphenol compounds, flavonoids, quinones and saponins. Polyphenol and flavonoid compounds are known to cause extracellular and intracellular proteins to form complexes with bacterial cell walls. The formation of this complex causes damage to the microsomes, lysosomes and bacterial cell walls. Flavonoids can also interfere with the intercalation 
Table 2. Results of Biochemical Test of P. acnes ATCC 11827 and MRSA ATCC BAA-1683

\begin{tabular}{lcc}
\hline $\begin{array}{l}\text { Biochemical } \\
\text { Test }\end{array}$ & $\begin{array}{c}\text { P. acnes } \\
\text { ATCC 11827 }\end{array}$ & $\begin{array}{c}\text { MRSA ATCC } \\
\text { BAA-1683 }\end{array}$ \\
\hline Glucose & - & + \\
Sucrose & + & + \\
Lactose & + & - \\
Manosa & - & + \\
Maltose & - & + \\
MR & - & - \\
VP & + & + \\
Citric & - & - \\
Motility & + & - \\
Urea & - & - \\
\hline
\end{tabular}

(formation of hydrogen bonds) between nucleotide bases, thereby inhibiting DNA and RNA synthesis. In addition, flavonoids can attack the dehydrogenase enzyme which is needed in energy metabolism, thereby inhibiting respiration and growth of bacterial cells. ${ }^{18}$

Quinones can form irreversible complex compounds with nucleophilic amino acid residues in transmembrane proteins, also with polypeptides in the cell wall and with various enzymes on the surface of the cell membrane, thereby disrupting the stability of bacterial cells. ${ }^{19}$ Saponins also reduce surface tension, thereby increasing cell wall permeability and resulting in the release of intracellular compounds. ${ }^{18}$

\section{Confirmation of Bacteria Test}

Microscopic observations of the results of Gram stain show that $P$. acnes ATCC 11827 is a Gram-positive rod-shaped bacterium, while MRSA ATCC BAA-1683 is a round Gram-positive bacterium with a grape-like arrangement. The results of biochemical tests showed that $P$. acnes ATCC 11827 was a motile bacterium that ferments sucrose and lactose, with a positive VP result. MRSA ATCC BAA1683 is a bacterium that ferments glucose, lactose, mannose and maltose, with a positive VP result (Table 3). The results of microscopic observations and biochemical tests are in accordance with the research of Shinkafi \& Ndanusa (2013) for P. acnes and research by Domon, et al. (2016) for MRSA. ${ }^{20,21}$

\section{Resistance of Bacteria Test}

The results of the resistance test showed that oxacillin produced an inhibitory diameter of $8.03 \mathrm{~mm}$ against MRSA ATCC BAA-1683. Based on the provisions of CSLI (2018), the diameter of the oxacillin inhibition of $\leq 10$ $\mathrm{mm}$ indicates that bacteria were resistant to oxacillin, while the diameter of the inhibition $\geq 13 \mathrm{~mm}$ indicatesd that the bacteria were sensitive to oxacillin. These results indicated that MRSA ATCC BAA-1683 was resistant to oxacillin. $^{14}$

Antibacterial Activity of Red Yeast Rice Extract The extract concentrations used for the 
Table 3. Test Result of Antibacterial Activity of Red Yeast Rice Extract against P. acnes ATCC 11827

\begin{tabular}{lccc}
\hline \multirow{2}{*}{$\begin{array}{l}\text { Extract } \\
(\mathbf{m g} / \mathbf{m L})\end{array}$} & \multicolumn{3}{c}{ Inhibition Diameter $(\mathbf{m m})$} \\
\cline { 2 - 4 } & n-hexane & Ethyl Acetate & Ethanol \\
\hline 100 & 0 & 10.35 & 9.53 \\
200 & 0 & 11.64 & 10.30 \\
400 & 0 & 13.11 & 13.47 \\
600 & 0 & 14.57 & 14.86 \\
\hline
\end{tabular}

Information: perforator diameter $=8 \mathrm{~mm}$

Table 4. Test Result of Antibacterial Activity of Red Yeast Rice Extract against MRSA ATCC BAA-1683

\begin{tabular}{lccc}
\hline Extract & \multicolumn{3}{c}{ Inhibition Diameter $(\mathbf{m m})$} \\
\cline { 2 - 4 }$(\mathbf{m g} / \mathbf{m L})$ & n-hexane & Ethyl Acetate & Ethanol \\
\hline 100 & 0 & 10.48 & 9.75 \\
200 & 0 & 11.88 & 11.90 \\
400 & 0 & 14.64 & 14.96 \\
600 & 0 & 15.77 & 16.72 \\
\hline
\end{tabular}

Information: perforator diameter $=8 \mathrm{~mm}$

antibacterial activity test were 100, 200, 400 and $600 \mathrm{mg} / \mathrm{mL}$ in DMSO $2 \% \mathrm{v} / \mathrm{v}$. The results of the antibacterial activity test show that ethyl acetate and ethanol extracts have activity against $P$. acnes ATCC 11827 and MRSA ATCC BAA-1683, but n-hexane extract does not have activity against these two bacteria (Tables 3 and 4).

Ethyl acetate extract was the most active extract against the two tested bacteria. The increase in the inhibitory diameter of the extract is directly proportional to the concentration of the extract. This was also observed in the inhibition diameter of the red pigment in red yeast rice against Bacillus subtilis, Bacillus meganterium, and Bacillus mycoides. The inhibitory diameter of the ethyl acetate extract was smaller than the $10 \mathrm{mg} / \mathrm{mL}$ inhibitory diemeter of the orange yellow pigment from red yeast rice against $\mathrm{E}$. coli by $21.3 \mathrm{~mm} .^{5,8}$
Determination of Minimum Growth Inhibitory Concentration (MIC) and Minimum Killing Concentration (KBM) of Red Yeast Rice Extract

MIC was only determined for the most active extract, namely ethyl acetate extract. The concentration of the extract stock solution used was $400 \mathrm{mg} / \mathrm{mL}$. From the results of the determination, it was found that the MIC value of ethyl acetate extract against $P$. acnes ATCC 11827 was $50 \mathrm{mg} / \mathrm{mL}$, while for MRSA ATCC BAA-1683 was $12.5 \mathrm{mg} / \mathrm{mL}$ (Table 5). The MIC value was greater than the MIC value of the orange yellow pigment from red yeast rice of $2.5 \mathrm{mg} / \mathrm{mL}$. This was because in this study extracts were still used, not pigment isolates as in previous studies. ${ }^{8}$

The MBC value of ethyl acetate extract against $P$. acnes ATCC 11827 was $100 \mathrm{mg} / \mathrm{mL}$, while for MRSA ATCC BAA-1683 was $25 \mathrm{mg} / \mathrm{mL}$ 
Table 5. Results of Determination of the MIC Value of Red Yeast Rice Ethyl Acetate Extract against $P$. acnes ATCC 11827 dan MRSA ATCC BAA-1683

\begin{tabular}{lcc}
\hline $\begin{array}{l}\text { Extract } \\
(\mathbf{m g} / \mathbf{m L})\end{array}$ & $\begin{array}{c}\text { P. acnes ATCC } \\
\mathbf{1 1 8 2 7}\end{array}$ & $\begin{array}{c}\text { MRSA ATCC } \\
\text { BAA-1683 }\end{array}$ \\
\hline 200 & - & - \\
100 & - & - \\
50 & - & - \\
25 & + & - \\
12.5 & + & - \\
6.25 & + & + \\
3.125 & + & + \\
1.562 & + & + \\
0.781 & + & + \\
\hline
\end{tabular}

Information: $(-)=$ no bacterial growth; $(+)=$ there was bacterial growth

(Table 6). From the results of MIC and MBC determination, it was found that ethyl acetate extract is more active against MRSA ATCC BAA-1683 than against $P$. acnes ATCC 1827.

\section{Conclusion}

Based on the results of this study, it can be concluded that the ethyl acetate extract and ethanol extract of red yeast rice have antibacterial activity against $P$. acnes ATCC 11827 and MRSA ATCC BAA-1683. Both extracts contain polyphenol compounds, flavonoids, quinones and saponins. Ethyl acetate extract is the most active extract with MIC values against $P$. acnes ATCC 1182 and MRSAATCC BAA- 1683 of $5 \mathrm{mg} / \mathrm{mL}$ and 12.5 $\mathrm{mg} / \mathrm{mL}$, respectively. The $\mathrm{MBC}$ values of ethyl acetate extract against $P$. acnes ATCC 11827 and MRSA ATCC BAA-1683 are $100 \mathrm{mg} / \mathrm{mL}$ and $25 \mathrm{mg} / \mathrm{mL}$, respectively. The ethyl acetate extract of red yeast rice is more active against MRSA ATCC BAA-1683 than P. acnes ATCC 11827. Based on the results of this study, it is found that red yeast rice has the potential to be used as an alternative antibacterial for bacteria that causes skin infections, especially against MRSA.

\section{References}

1. Dréno B, Pécastaings $\mathrm{S}$, Corvec S, Veraldi S, Khammari A, Roques C. Cutibacterium acnes (Propionibacterium acnes) and acne vulgaris: a brief look at the latest updates. Journal of European Academy of Dermatology and Venereology. 2018;32(Suppl.2):5-14.

2. Zaenglein AL, Pathy AL, Schlosser BJ, et al. Guidelines of care for the management of acne vulgaris. Journal of the American Academy of Dermatology. 2016;74(5):945973.e33.

3. Stevens DL, Bisno AL, Chambers HF, et al. Practice guidelines for the diagnosis and management of skin and soft tissue infections: 2014 update by the infectious diseases society of America. Clinical Infectious Diseases. 2014;59(2):10-52.

4. Dekker ARJ, Verheij TJM, van der Velden AW. Inappropriate antibiotic prescription for respiratory tract indications: Most prominent in adult patients. Family Practice. 2015;32(4):401-407.

5. Mukherjee G, Singh SK. Purification and characterization of a new red pigment from Monascus purpureus in submerged 
fermentation. Process Biochemistry. 2011;46(1):188-192.

6. Patakova P. Monascus secondary metabolites: Production and biological activity. Journal of Industrial Microbiology and Biotechnology. 2013;40(2):169-181.

7. Dikshit R, Tallapragada P. Comparative study of Monascus sanguineus and Monascus purpureus for red pigment production under stress condition. International of Food Research Journal. 2013;20(3):1235-1238.

8. Zhao GP, Li YQ, Yang J, Cui KY. Antibacterial characteristics of orange pigment extracted from monascus pigments against Escherichia coli. Czech Journal of Food Science. 2016;34(3):197203.

9. Manan MA, Ariff A, Mohamad R. The Morphology and Structure of Red Pigment Producing Fungus: Monascus Purpureus. Journal of Microbiol and Experimentation. 2017;5(1).

10. Chaerunisaa AY, Milanda T, Susilawati Y. Activity of Cassia fistula L. Barks fractions as antibacterial agent. Journal of Pharmaceutical Science Research. 2018;10(2):304-309.

11. Chaerunisaa AY, Susilawati Y, Muhaimin M, Milanda T, Hendriani R, Subarnas A. Antibacterial activity and subchronic toxicity of Cassia fistula L. barks in rats. ToxicologiReports. 2020;7(April):649-657

12. Saputri FA, Kang D, Kusuma ASW, et al. Lactobacillus plantarum IS-10506 probiotic administration increases amlodipine absorption in a rabbit model. Journal of International Medical Research. 2018;46(12):5004-5010.

13. Ferdioz J, Roy A. Antibacterial activity of aqueous alcoholic extract of abutilon indicum aerial parts against enterococcus faecalis - an in Vitro study. Asian Journal of Pharmacy Clinical Research. 2017;10(5):80-81. ajpcr.2017.v10i5.15636

14. CSLI. M02:Performance Standards for Antimicrobial Disk Susceptibility Tests. 13th ed. CSLI; 2018.

15. Ben Lagha OM, Zakaria MP, Ismail IS, Nor-Khaizura MAR, Rukayadi Y. Antibacterial activity of nutmeg (Myristica fragrans houtt.) extract against foodborne pathogens on raw beef during chilled and frozen storage. Food Research. 2020;4(2):380-388.

16. Ismail AI, Falah S, Faridah DN. Alpha Glucosidase inhibition by Red Yeast Rice Extract and Fractions as In vitro Antidiabetes. Der Pharma Chemica. 2016;8(22):46-49.

17. Kongbuntad W, Saenphet S. Effects of Red Mold Rice Produced from Monascus purpureus CMU002U on Growth Performances and Antioxidant Activity of Japanese Quail. International Journal of Poultry Science. 2016;15(1):8-14.

18. Ngajow M, Abidjulu J, Kamu VS. Pengaruh Antibakteri Ekstrak Kulit Batang Matoa (Pometia pinnata) terhadap Bakteri Staphylococcus aureus secara In vitro. Jurnal Pendidikan MIPA. 2013;2(2):128.

19. Sapara TU, Waworuntu O. Efektivitas Antibakteri Ekstrak Daun Pacar Air (Impatiens Balsamina L.) Terhadap Pertumbuhan Porphyromonas Gingivalis. Pharmacon. 2016;5(4):10-17.

20. Shinkafi S, Ndanusa H. Antibacterial Activity of Citrus Limon On Acne Vulgaris (Pimples). International Jorunal of Science Inventions Today. 2013;2(5):397409.

21. Domon H, Uehara Y, Oda M, Seo H, Kubota N, Terao Y. Poor survival of Methicillin-resistant Staphylococcus aureus on inanimate objects in the public spaces. Microbiology Open. 2016;5(1):3946. 